\title{
UNDERSTANDING THE PREJUDICES IN ORDER TO IMPROVE THE IMAGE OF TURKEY: A QUALITATIVE STUDY ON THE PREJUDICES OF ITALIANS ABOUT TURKEY
}

\author{
İPEK ALTINBAŞAK \\ Bahçeşehir University
}

\begin{abstract}
Several studies have indicated that country image has an affect on the forces contributing to the development of the country in question. Prejudices, which are formed over time, are also thought to influence people's decisions related to visiting a country, buying its products or evaluating its people. That is why, in order to implement a successful country image management strategy, it is worthwhile to investigate and attempt to overcome those prejudices. This study explores how prejudices affect Turkey's image, and makes suggestions on how to change these prejudices. Acknowledging that the image of a specific nation differs from country to country, this study is based on one example, namely Italy. Using the focus group technique, Italians living in Turkey were asked about the prejudices they had had about Turkey before directly experiencing it and about whether or not those prejudices had affected their perception after their experience. The prejudice and image themes derived from the content analysis are examined and contrasted using the eight meta-themes developed.
\end{abstract}

The study confirms that prejudices occur because of incomplete information either as a result of personal disinterest or biased information acquired from different sources. Young people rely more on the opinions of peers whereas with age, the impact of media increases. The findings of the study suggest that direct contact with Turkey and its people prove to be successful in changing the prejudices and improving the image of Turkey. Therefore, academic, commercial and tourism related interactions need to be fostered between Italy and Turkey. Especially, student exchange programs targeted at young people and activities underlining the status and rights of women in Turkey have to be developed, and the secularism of the state has to be emphasized in order to change prejudices and improve the image of Turkey.

Key words: country image, place marketing, prejudice, stereotype, Turkey's image, strategic image management, Turkish-Italian relationships.

* İpek Altınbaşak is an Assistant Professor in the Department of Business Administration at Bahçeşehir University, Çırağan Caddesi, 34353, Beşiktaş, Istanbul, Turkey. E-mail: ipek.altinbasak@ bahcesehir.edu.tr 


\title{
TÜRKIYE IMAJINI GELISTTIRMEK AMACI ILLE ÖNYARGILARI ANLAMAK: ITALYANLARIN TÜRKIYE ILE ILGILII ÖNYARGILARI ÜZERINNE NITELIKSEL BIR ÇALIŞMA
}

\begin{abstract}
ÖZET
Yapılan araştırmalar ülke imajının, söz konusu ülkenin gelişiminde rol oynayan çeşitli faktörler üzerinde etkili olduğиnu ortaya koymaktadır. Zaman süreçlerinde oluşan önyargllar ise, ülkelerin algılarının şekillenmesine katkıda bulunmakta ve ülkenin ziyaret edilmesi, ürünlerinin alınması veya insanlarının de ğerlendirmesinde rol oynamaktadırlar. Başarılı bir ülke imaj yönetim stratejisi uygulayabilmek için, ülke imajına etki eden bu önyargıların anlaşılması ve olumlu yönde değiş̧irilmek üzere çalışılması önem kazanmaktadır. Bu çalışma, önyargıların Türkiye imajını nasıl etkilediğini irdelemeyi amaçlamakta ve bu önyargıları bertaraf etmek için öneriler ortaya koymaktadır. Bir

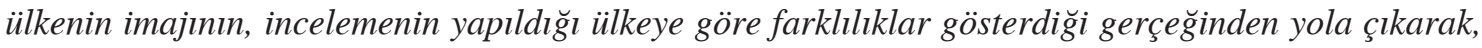
bu çalışma tek bir örnek, İtalya üzerine yoğunlaşmaktadır. Odak grup tekniği kullanılarak, Türkiye'de yaşamakta olan Italyanlar'a Türkiye’ye gelmeden önceki önyargıları sorulmuş, bu önyargıların Türkiye algılarını etkileyip etkilemediği ve Türkiye’deki deneyimleri neticesinde değişip değişmediği irdelenmiştir. Ortaya çıkan önyargı ve imaj konuları, yapılan içerik analizi sonucunda belirlenen sekiz meta başlık altında toplanarak incelenmiş ve karşılaştırılmıştır.
\end{abstract}

Katılımcılar, özellikle bireylerin bizzat derinlemesine araştırma yapmadıklar durumlarda, yanlı kaynakların yönlendirmesi bazen de bilgi eksikliğgi sebebi ile oluşan önyargıların ülke imajı üzerinde etkili olduğunu ifade etmişlerdir. Gençler daha çok arkadaş çevresinden edindikleri bilgiler ışı̆̆ında ülke imajını şekillendirirken, yaş ilerledikçe medyanın etkisi artmaktadır. Çalışma, bir ülke ve o ülkenin insanları ile doğrudan iliş̧kinin önyargıları değiştirmede etkili olduğuna ve Türkiye örneğinde de alglyı olumlu yönde geliştirdiğine işaret etmektedir. Bu sebeple akademik, ticari ve turizm alanındaki işbirliklerinin artması Türkiye'nin Italya'da daha iyi tanınarak, önyargıların bertaraf edilmesine katkı sağlayacaktır. Özellikle gençlerin Türkiye’yi tanımasına yönelik de ğişim programlarının, Türk kadınların konumu ve haklarının, aynı zamanda laik sistemin vurgulanmasının, Türkiye ile ilgili önyargıları değistirmek ve imajını olumlu yönde etkilemek amacı ile etkili olacă̆ ifade edilmektedir.

Anahtar kelimeler: ülke imajı, mekan pazarlaması, önyargl, stereotip, Türkiye imajı, stratejik imaj yönetimi, Türkiye-Ittalya ilişkileri.

The concept of image has attracted a great deal of interest among academics as well as marketing practitioners. Image can simply be defined as "the sum of the total impressions [the] consumers receive from many sources" (Herzog, 1963). Image, as a mental representation, is also described as a network of meanings stored in the memory, in a particular structure, and along with affective, motivational and sensory aspects (Ger and Askegaard, 1996). This subject has been investigated using numerous research approaches throughout the years, particularly focusing on brand image, which is an essential part of positioning and marketing strategy. Another area which has received attention from scholars is the image of a country in the context of a product. As a result of companies shifting their production to countries where costs are low, and of the increasing volume of international trade, the country-of- 
origin effect has become a major topic of investigation. It is argued that the evaluation of a product or service is affected by the image of the country in which it originated, which, in turn, influences the purchase decisions of consumers (Erickson et al., 1984; Johansson et al., 1985; Han, 1989).

The image of a country has crucial impacts not only on the assessment of its products abroad, but also on the forces contributing to the country's development. The media, the Internet and other communication vehicles facilitate the rapid flow of information and decrease the distances between places and people. Yet country image, which is a multi-dimensional phenomenon developed over centuries, may not be changed as quickly. This image is created by such variables as economic and political environment, geographical location, prior experiences with the country and its people, and especially by history and traditions over a long period of time (Altınbaşak, 2004). The cultural and historical relationships between countries are also thought to result in prejudices affecting the perception of the country in question (Altınbaşak 2004, 2008). Especially, when there is a lack of information, prejudices serve as cues to assess countries, their people and their products. Therefore, it is worth investigating the prejudices related to a country in order to overcome them with the objective of creating a more positive country image.

On October 3, 2005 Turkey started the official process for accession to the European Union. Research results indicate that even if Turkey implements the required reforms, the public opinion in several countries is not in favor of its accesion (Eurobarometer, 2006). Therefore, besides implementing tangible and permanent reforms, Turkey has to change the opinion of the public and the decision makers in the member countries of the European Union about itself. That is why, it is necessary to understand the prejudices and perceptions related to Turkey in order to be able to manage the country image. The purpose of this study is to explore the prejudices related to Turkey taking Italy as a case and to provide insights for improving the country image.

In the first part of the paper the literature related to country brand image, stereotypes and prejudices, followed by the image studies related to Turkey are examined. Next, the research objectives and methodology of the study are presented. The findings section covers the prejudice and image themes related to Turkey. Finally, the relationships between prejudice and image themes are analyzed to provide suggestions for improving the image of Turkey.

\section{LITERATURE REVIEW}

In several studies it is argued that a country name can serve the same function as a brand. Just like commercial brands, country brands are well understood by consumers around the world and have long-established identities. They can work just as effectively as an indicator of product quality and a definer of image and target market as can the manufacturer's name on the package (Anholt, 2000). It is obvious that a nation, similar to a brand, develops an image over time. A nation, as well, needs to be positioned, differentiated and marketed in different arenas, and its image has to be managed just as one might manage that of a brand. Many scholars argue that images are not inherent in the brand, but instead are qualities that people associate with it (Dunn and Barban, 1982; Aaker and Myers, 1987). Therefore, understanding those associations becomes crucial for brands as well as for countries in order to develop strong positions vis-à-vis competitors. Martineau (1987) claims that brand image is a halo of psychological meanings, the associations of feeling, and the undeniably written aesthetic messages over and above the physical qualities. This is also true for country image. A brand's native 
country is thought to behave exactly like the parent company of a brand (Anholt, 2000). Therefore, many brand image concepts can also be applied to the country image notion.

The relationship between national image and brand image has also been an area of interest in marketing literature (Niss, 1996). It has been argued that to the extent that consumers have a negative image for a given country, they will probably develop negative images of the people of that country, and consequently this will affect their attitudes towards the county's products (Srikatanyoo and Gnoth 2002; Morello, 1984). Laroche, et al. (2005) argue that country image is a three-dimensional concept consisting of cognitive, affective and connative components. Martin and Eroğlu (1993: 191) define country image as "the total of all descriptive, inferential, and informational beliefs about a particular country." They also claim that country image cannot be controlled by a company's efforts, nor can it be administered by means of its marketing practices. Studies have documented that country image or equity is influenced by external factors such as the country's economic status, technology, social desirability, the characteristics of its people, and natural image.

Stereotypes are sets of beliefs about the personal attributes of a group of people. Liu and Johnson (2005) argue that "country stereotypes" significantly influence country-of-origin evaluations. Bannister and Saunders (2001) aim at revealing the stereotyped attitudes of consumers towards a selection of foreign countries. Country image may vary according to the geographical proximity, cultural contact and familiarity of the respondent with that country (Ger and Askegaard, 1996).

Stereotyping is inaccurate and often derogatory. It prejudges a person's or country's potential on unfair assumptions about racial, physical or cultural traits. Similarly prejudices are defined as biased evaluations of or generalized attitude towards members of a group. They are, in general, negative images resulting from lack of information or biased beliefs. Stereotypes and prejudices are also thought to be influential in people's decisions related to visiting a country, buying its products or evaluating its people (Altınbaşak, 2004, 2008).

In the specific case of Turkey, the results of a Eurobarameter survey (2006) indicate that there is a negative public opinion related to Turkey's accession to the EU. Similarly, in the Nation Brand Index of Anholt (2005) Turkey occupies the last ranks related to many dimensions, pointing out that Turkey does not have a strong image in the eyes of the foreign public. Research carried out on the image of Turkey (Kemming and Sandıkçı, 2007; Altınbaşak, 2004, 2008) points out several issues on the "otherness" concept in regards to the religion, language, lifestyle, physical appearance and culture in general. The research carried out specifically with Italians also sheds light on the existence of prejudices related to Turkey and Turkish people (Altınbaşak, 2004, 2008). The exotic image of Turkey and the fears related to the security, human rights, women's rights and secularism of the country reinforce the prejudices. As Kemming and Sandıkçı (2007: 38) point out, “Turkey's image will need to undergo changes and a clearer picture of the nation brand will need to be perceived when the time comes to finally decide on Turkey's accession." Therefore, discovering the prejudices related to Turkey can be of help to improve its country image.

\section{THE RESEARCH}

This study aims to explore the prejudices related to Turkey, taking Italy as a case, and to provide insights for improving the country image. Italy has been chosen for the following reasons: (1) Turkey 
has always had strong economic, cultural and political relationships with Italy; (2) Italy is among the countries with which Turkey has the most trade; (3) There is a considerable level of Italian foreign investment in Turkey, and it is desirable to further develop these investments; (4) Both countries are Mediterranean and compete in the tourism sector; and (5) Previous empirical research revealed that Italians who had close relationships with Turkey and Turks historically had certain prejudices which affected their image of Turkey (Altınbaşak, 2004, 2008).

In order to explore the prejudices about Turkey and the country image, qualitative research techniques were implemented. Two focus group interviews, each consisting of six Italians, were conducted. The interviewees were selected from among Italians who currently live or work in Turkey. To choose the participants the criteria of the duration of stay, gender and age of the respondents were used. Following a structured protocol (see Appendix 1), the participants were asked about their perceptions of Turkey and the prejudices which had affected them. If the data collected were not rich and robust enough, a third focus group interview was planned. However, the third focus group was deemed unnecessary as the information obtained in the first two focus groups provided the necessary clarity and consistency. As summarized in Table 1, six male and six female participants from different age groups participated in the study. The average age of the participants was around 40 and the average length of their stay was 10 months.

Table 1

Characteristics of the Participants

\begin{tabular}{lccc}
\hline & GENDER & AGE & $\begin{array}{c}\text { DURATION OF } \\
\text { THE STAY }\end{array}$ \\
\hline PARTICIPANT 1 & Female & Late 20s & 21 months \\
PARTICIPANT 2 & Male & Early 40s & 10 months \\
PARTICIPANT 3 & Female & Late 50s & 1 month \\
PARTICIPANT 4 & Female & Late 50s & 10 months \\
PARTICIPANT 5 & Male & Teenager & 10 months \\
PARTICIPANT 6 & Male & Late 50s & 1 month \\
PARTICIPANT 7 & Female & Early 40s & 30 months \\
PARTICIPANT 8 & Male & Late 20s & 5 months \\
PARTICIPANT 9 & Female & Late 30s & 1 month \\
PARTICIPANT 10 & Male & Late 30s & 11 months \\
PARTICIPANT 11 & Female & Early 40s & 10 months \\
PARTICIPANT 12 & Male & Late 50s & 10 months \\
\hline
\end{tabular}

The moderator spoke Italian and was familiar with the country image study and interviewing techniques. The interviews were carried out in the mother tongue of the participants and lasted around two and a half hours each. With the participants' permission, all interviews were video recorded.

One of the basic approaches to analyzing qualitative data is systematic coding via content analysis (Weber, 1990). After the interviews, the transcripts of the sessions were analyzed by two independent coders and a detailed decoding of the process was carried out. Both coders defined the themes and then 
classified them under meta-themes. Furthermore, negative and positive connotations were examined in order to understand the general direction, both for the prejudices and for the image variables. The coders discussed their analysis with the researcher and agreed on the meta themes. Afterwards, two independent judges placed the themes under the meta themes developed.

Through the analysis, a total of 40 topics about the prejudices and 46 topics about the current image were identified, analyzed and classified into content categories by two sorters and two judges. The reliability of this process was measured by calculating the agreement level between the coders and the judges, according to the method discussed by Zimmer and Golden (1988). The percent agreement between the judges was found to be statistically significant, with $88 \%$ reliability related to the prejudice themes and $90 \%$ reliability related to the image themes was obtained (see Appendix 2 for the methodology used related to content analysis and the reliability figures).

The findings on the prejudices were compared with the themes related to the current image of Turkey in order to discuss their relationships.

The study is exploratory in nature and does not aim to develop a model. It is concentrated on one country and therefore does not strive to compare and contrast the prejudices which exist in the minds of different nationalities.

\section{FINDINGS OF THE RESEARCH}

Regardless of age, gender and duration of stay, all of the respondents admitted that prejudices exist towards almost every country. They also believed that in the $21^{\text {st }}$ century nobody relies solely on prejudices to evaluate a country, its people or its products. On the other hand, even if prejudices are not relied on completely, as they are formed over time and through experience, it is believed that they may have some truth in them. The participants defined "prejudice" as (the numbers in parentheses represent the frequency of mentions):

- subjective evaluation (5)

- fixed clichés (2)

- a result of ignorance (4)

- banality (1)

- $\operatorname{gossip}(2)$

- a suspicion that may contain some truth in it (3)

- misinformation (4)

- False ideas reflecting either a fear or an absolute enthusiasm (5)

The respondents claimed that negative prejudices stem from social learning and threats. The respondents believe that prejudices are always developed by those who feel superior to others. Furthermore, those prejudices are created in many cases by those who have an interest in developing a certain attitude toward the other in question. This interest can be political, economic or just social; it can provide cues and develop certain attitudes in line with beliefs. 
The study reveals that prejudices are especially relevant in the cases where: (a) one does not have any interest in the country, (b) one does not have time to investigate the issues related to that country in different sources of information, and (c) one has not had contact, even accidentally, with the country or its people. Therefore, lack of knowledge can be seen as a major influence on the formation of prejudice on country image.

\section{PREJUDICES ABOUT TURKEY}

Except for the ones who had been in Turkey for travel purposes (three out of twelve) and the ones who already had an interest in Turkey and studied the country before coming (two out of twelve), more than half of the respondents admitted that they had not had any knowledge about Turkey prior to coming. Therefore, they were more prone to be influenced by the media and by word-of-mouth information. Those who had already been to Turkey for short periods of time had developed different images, some supportive of, some contrary to, their previous prejudices.

It is also observed that there is a difference between people of different ages with respect to the sources that influenced their prejudices. The younger respondents relied more on the comments of their friends and word-of-mouth information. However, as age increases, the importance of information in the print media and television also increased. The participants admitted that the media may not always be objective and many times may reflect only the negative issues reported from their own perspectives. Therefore, especially for the people who can not research the subject to check the information's reliability, the media play a crucial role in the formation of prejudices.

The older respondents mentioned that they had learned about Turkey in history lessons at school. As confirmed in other research (Altınbaşak, 2004), although several ancient civilizations are known by Italians, only a few had knowledge that many of those civilizations existed within the current borders of the Turkish Republic. Interestingly, several movies related to Turkey or Turkish people were recalled by many of the respondents. There was a consensus among the participants that images of Turkey and Turkish people depicted in those movies, which reach a huge number of people, create prejudices. Themes related to the participants' prejudices towards Turkey are summarized in Table 2.

As it can be observed, only $25 \%$ of the prejudices mentioned about Turkey and Turks were positive, whereas $75 \%$ of the prejudices mentioned were negative.

\section{THE IMAGE OF TURKEY}

After their stay in Turkey, the respondents formed images of Turkey and Turkish people. These themes related to the image are summarized in Table 3.

In cases where participants had visited Turkey, more than half (56\%) of the areas mentioned received positive responses, whereas $44 \%$ were negative. 
Table 2

The Themes Related to Prejudices

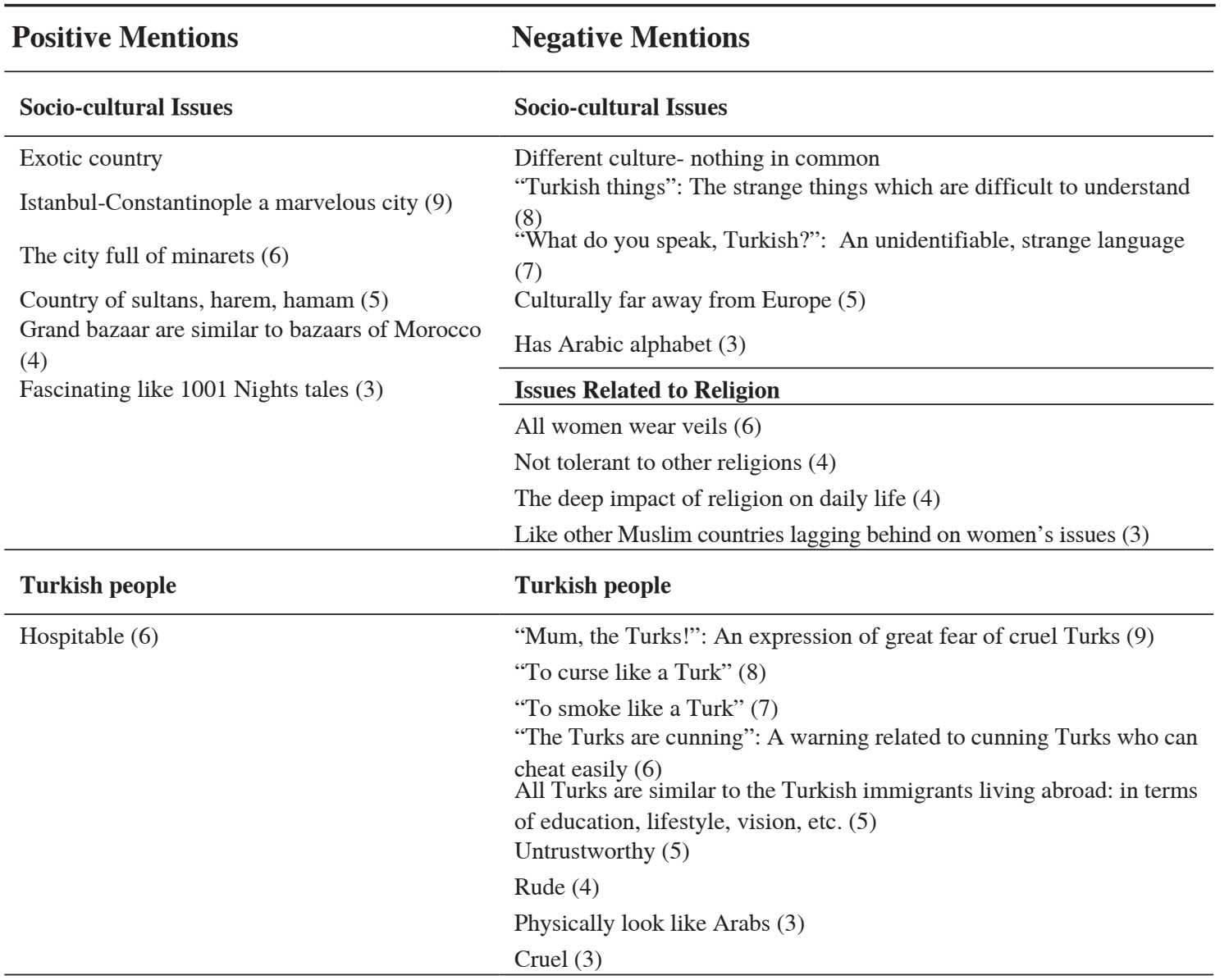

\section{Geographical Landscape / Nature/ Climate}

Beautiful sea- Mediterranean coast (6)

Always hot country- ideal for vacation (5)

\section{Geographical Landscape / Nature/ Climate}

Turkey is geographically far away from Europe (7)

No attention for the preservation of nature (4)

\begin{tabular}{l}
\hline Political Environment \\
\hline Concerns about the application of secularist rules (7) \\
Nationalistic country (6) \\
Kurds are badly treated in Turkey (3) \\
Armenian genocide issue not clarified (2) \\
\hline Economic Environment \\
\hline Underdeveloped country (5) \\
Poor country (5) \\
Country difficult to do business for foreigners (4) \\
\hline Issues Related to Security \\
\hline Bombs everywhere (6) \\
\hline Issues Related to Hygiene \\
\hline No attention for hygiene (4)
\end{tabular}

\section{Total Mentions: Positive: 10}

*the numbers in parentheses represent the frequency of mentions 
Table 3

Themes Related to the Image of Turkey

\begin{tabular}{|c|c|}
\hline Positive Mentions & Negative Mentions \\
\hline Socio-cultural Issues & Socio-cultural Issues \\
\hline Modern like other metropolitan cities (Istanbul)(10) & Difficult language creates a barrier (9) \\
\hline Young (10) & Heavy traffic (8) \\
\hline Full of suprises (9) & Chaotic (7) \\
\hline Rich in history & Strong sense of hierarchy (6) \\
\hline There is an explosive energy (8) & Rigid education system (3) \\
\hline Much cleaner than expected (8) & $\begin{array}{l}\text { Education system reinforces stability and obeying the rules } \\
\text { instead of supporting the development of new ideas to change } \\
\text { the status quo (3) }\end{array}$ \\
\hline \multicolumn{2}{|l|}{ Beautiful country (8) } \\
\hline \multicolumn{2}{|l|}{ Beautiful historical monuments (8) } \\
\hline \multicolumn{2}{|l|}{ Lively, moving city (7) } \\
\hline \multicolumn{2}{|l|}{ Dynamism everywhere (7) } \\
\hline \multicolumn{2}{|l|}{ Country full of contrasts (6) } \\
\hline \multicolumn{2}{|l|}{ With so much diversity-different faces (6) } \\
\hline \multicolumn{2}{|l|}{ Strong sense of family (5) } \\
\hline \multicolumn{2}{|l|}{ Country unique with own characteristic position (4) } \\
\hline Turkish People & Turkish People \\
\hline Friendly (6) & Sensitive about certain issues, not flexible (5) \\
\hline Sincere (6) & Too many people smoke (4) \\
\hline Many women in highest managerial positions (5) & $\begin{array}{l}\text { Young people not interested in what is going on outside Turkey } \\
\text { (4) }\end{array}$ \\
\hline \multirow[t]{5}{*}{ Happy (4) } & $\begin{array}{l}\text { More concerned with defending the past than developing the } \\
\text { future (3) }\end{array}$ \\
\hline & Issues Related to Religion \\
\hline & Gaining closer ties to other Islamic countries (7) \\
\hline & Lack of tolerance to those who do not respect Islamic rules (5) \\
\hline & Restrictions about alcohol and pork (4) \\
\hline \multicolumn{2}{|l|}{ Geographical Landscape/ Nature/ Climate } \\
\hline \multicolumn{2}{|l|}{ Bosphorus is splendid and unique (10) } \\
\hline \multicolumn{2}{|l|}{ Nice climate $(8)$} \\
\hline \multicolumn{2}{|l|}{ Good food, fruits and vegetables (5) } \\
\hline & The Political Environment \\
\hline & Policemen everywhere (6) \\
\hline & Nationalistic (6) \\
\hline & Limited circulation of ideas: poor media structure (5) \\
\hline Issues Related to Hygiene & Lack of liberty for expression (4) \\
\hline No hygiene problems, in general (9) & No tolerance for opposing ideas (4) \\
\hline The Economic Environment & The Economic Environment \\
\hline Rapid development (8) & Underdeveloped infrastructure (4) \\
\hline \multicolumn{2}{|l|}{ Country with big potential (7) } \\
\hline \multicolumn{2}{|l|}{ An attractive market for investors (6) } \\
\hline Issues Related to Security & Issues Related to Security \\
\hline A secure country to live in (7) & The terrorist attacks cause fear (5) \\
\hline Total Mentions: Positive: 26 & Negative: 20 \\
\hline
\end{tabular}

*the numbers in parentheses represent the frequency of mentions 


\section{ANALYSIS OF THE RELATIONSHIPS BETWEEN PREJUDICES AND THE IMAGE OF TURKEY}

In this section, the findings related to prejudices are compared with themes about Turkey's image as stated by the respondents ( $\mathrm{P}=$ prejudice themes, $\mathrm{I}=$ image themes). The eight meta-themes related to prejudices derived from the research are: (1) socio-cultural issues, with a specific emphasis on education, (2) Turkish people, (3) religion, (4) geographical landscape/nature/climate, (5) political environment, (6) economic environment, (7) security, and (8) hygiene.

\section{Socio-Cultural Issues}

(P1) These are defined as issues related to the culture and living style of the country. Turkey is thought to be an exotic country, very similar to Arab ones. For the participants who had been positively affected, there is the influence of history, but still an expectation for an exotic oriental world as depicted in the classic 1001 Nights tales. The participants stated that there was a tendency to consider Turkey similar to other Middle Eastern or Arab countries.

(I1) After their encounter with Turkey, all of the respondents admitted their stereotypes about Turkey being an Arab country had been totally wrong and due to a lack of knowledge. They found Turkey to be beautiful, fascinating and unique. The respondents clearly stated that Istanbul does not reflect the whole of Turkey. The country has many faces and many different things to offer. The culture is still defined as different, but it is also considered to be attractive in certain aspects. The preservation of values, family ties and traditions is appreciated. Turkey was also described as a rapidly developing country with a young population and big potential. Moreover, participants defined Turkey as being full of energy, having the desire to transform, and having a sense of dynamism which is lacking in Europe.

(P2) Many expressions about Turks that were developed centuries ago are still used in Italy today, all of which carry negative connotations (See Table 2). For example, the expression "What do you speak, Turkish?" is used for any unidentifiable, strange language. It is believed that the Arabic alphabet is still used in Turkey and this is in part why it is considered so difficult to understand Turkish. Anything which is strange to their culture is considered to be "Turkish things."

(I2) The stereotypes about the Turkish language limiting communication are perpetuated despite the respondents knowing that the Latin alphabet is used. This is likely due to the dissimilarity of the Turkish language to Latin-based languages.

(P3) The standing and rights of women in Turkey is another unclear issue. Turkish women are expected to have a much inferior role compared to men in society. The respondents were not informed that the Turkish Assembly, under the leadership of Ataturk, gave the right to vote and be elected to women in 1934, long before many developed European countries (i.e., Switzerland). The images of veiled Turkish women in the foreign media create negative impressions about the status of women in Turkey.

(I3) Many respondents were surprised to see so many Turkish women in the business place. Although a group of women live at the standards of their European counterparts, the participants still observed that not all women have the same living conditions. 
(P4-I4) Although there was no specific mention related to the prejudices about the education system in Turkey, the respondents evaluated the current image and criticized the Turkish education system in terms of it being rigid and not allowing the young people to develop their own ideas.

\section{Turkish People}

(P1) The expressions mentioned in Table 2 about Turks reflect the sources of negative images about Turkish people. Together with the prejudices formed in history, movies are stated to be very influential sources that create and reinforce prejudices. The respondents referred to many movies where Turks are depicted as untrustworthy, cunning, rude and impolite people. Only the ones who had friends or who had visited Turkey had observed the hospitality of the Turkish people.

(I1) Contrary to the prejudices developed by those expressions, many of the respondents stated that Turks were honest, sincere and friendly people. However, they recommended that the Turkish youth be more open to new ideas, try to understand what is going on around the world and be able to contribute to the development of the country.

On the other hand, the prejudice that Turks are heavy smokers was supported, especially due to the fact that during the period in which the research was conducted, people were allowed to smoke in public places.

(P2) The respondents stated that the Turkish immigrants living in other European countries created negative images of Turkish people and their living style.

(I2) As some Turkish immigrants refuse to integrate into the European culture, the state of the immigrants still depicts a negative image of Turkey.

\section{Religion}

(P1) The respondents stated that especially after 9/11, concerns about Muslim people had grown. There exist stereotypes for Muslim countries, and for people who have not been to Turkey, it is imagined to be similar to Arab countries. Therefore, Turkey is considered not only to be lagging behind on women's issues, but because of the Islamic religion, women are expected to have very little liberty and participation in social life. The main concern of the female foreigners who came to Turkey was the fear that they would have to wear the headscarf; they believed that all Turkish women were veiled. It was also thought that there was little tolerance for other religions.

(I1) The female participants were relieved when they saw that they did not have to wear a veil. Many of the prejudices mentioned above had been eliminated. Some of the respondents stated that they still had concerns about Turkey's developing closer relationships with Muslim countries and moving away from European countries resulting in the lack of tolerance for those who did not follow Islamic rules. As supported by other research (Altınbaşak, 2008; Kemming and Sandıkç1, 2007), the main issue was stated to be the extent of religious practice in the daily life.

\section{Geographical Landscape/Nature/Climate}

(P1) Through word-of-mouth most of the participants had heard about the beautiful coasts in Turkey. 
However, it was also communicated that Turkey did not care about nature preservation. For many people, Turkey was perceived as a hot country throughout the year. An important finding is related to the geographical distance between Turkey and Italy. The respondents, like many other friends and their relatives, considered Turkey to be far from Italy. When it was mentioned that it is only a two-hour flight away, many people were surprised. This is also evidence of how a lack of knowledge creates psychological distances, rendering even the geographical distances to appear more than they really are.

(I1) Supporting the positive prejudices, the Bosphorus and Istanbul are considered to be unique, and the Turkish coasts are admired for their beauty. However, the respondents stated that they had discovered to their great surprise that the climate was not always hot and that it snowed in different parts of Turkey. The quality and the abundance of the food, fruits and vegetables were also appreciated.

\section{Political Environment}

(P1) Prejudices about the political environment in Turkey were primarily related to concerns about the implementation of secularism, as a result of concerns related to religion. The respondents stated that Turkey had been seen as a nationalistic country. Furthermore, the Kurdish and Armenian issues as presented by lobbying groups reflected their own biased perspective. Certain negative prejudices related to Turkey, therefore, existed because of these issues.

(I1) The respondents who had the opportunity to investigate in more detail the Kurdish and Armenian issues in Turkey were able to develop their own perspective independent of sources that worked to promote certain ideas. Turkey was still considered to be a very nationalistic country in line with prior prejudices.

\section{Economic Environment}

(P1) Turkey was perceived as an underdeveloped and poor country. It was also considered a difficult environment for foreigners to do business in because of the volatile status of the economy, fears of cultural differences and the language barrier.

(I1) Contrary to the above-stated prejudices, Turkey was considered to be an attractive market for foreign investors because of its rapid development and large, young population.

\section{Security}

(P1) The terrorist attacks, covered extensively by the foreign media, created concerns about security issues in Turkey. It was stated that many people were afraid to travel or preferred not to travel specifically because of these concerns. The participants living in Istanbul stated that it had become difficult to convince their relatives who had not been to Turkey about the actual security situation in Turkey.

(I1) Some of the respondents still believed that Turkey was chaotic and a difficult country in which to raise children. On the contrary, many stated that Istanbul was much safer compared to other metropolitan cities in Europe. Worries about the lack of tolerance for those who did not follow Islamic rules were also considered as an issue of security. 


\section{Hygiene}

(P1) Before visiting Turkey, some of the respondents had worries about hygienic problems similar to ones they experienced in North African countries.

(I1) They, however, stated that the hygenic level to be good in Turkey contrary to their prejudices.

\section{DISCUSSION AND SUGGESTIONS}

The research is of an exploratory nature and aims at providing insights as to the country image of Turkey and how this image can be improved through understanding the prejudices. Although the findings can not be generalized, they are expected to highlight the main prejudices in the minds of Italians related to Turkey and examine ways to overcome them with the objective of creating a positive country image for Turkey.

The respondents clearly admitted that their prejudices were the result of a lack of prior knowledge or experience. While modern communication technologies enable people to acquire all kinds of information regardless of place and time, individuals do not have the time or interest to make detailed investigations about every subject. Therefore, when there is a lack of information, prejudices serve as cues to assess countries, their people and their products. That is why, in order to manage the image of Turkey by eliminating negative prejudices and promoting positive ones, a strategic image management approach must be applied. The participants in the survey also stated that Turkey should work more on promoting itself and should engage in lobbying activities in order to provide relevant information about Turkey abroad.

The findings suggest that it is crucial to increase the level of contact between Turkey and Italy. Given the rich historical heritage of Turkey and the beautiful natural landscape, Turkey should invest in attracting more Italian tourists. Moreover, bilateral cooperation between businesspersons, sports persons, and artists should be encouraged. The exchange of students between countries would help the development of mutual understanding among the young people. Cultural events are very important opportunities to promote a country. Therefore, all the activities relating to Istanbul, which has been designated the "European Capital of Culture" for 2010, have a major impact on the country's image formation.

The findings also suggest that clarification of the status of women in Turkey has very important implications in eliminating many prejudices. That is why, in a period in which Turkey is working for accession to the European Union, all governmental and non-governmental institutions should encourage and invite modern Turkish women to be more active in bringing the image of Turkey to the forefront.

The differences between cultures stated in this study should be turned into opportunities to learn about each other. As a country with a dominant Muslim population, Turkey should put more emphasis on secularism, differentiating it from countries where Islamic law rules.

Prejudices abroad can be changed by accurate facts and by the dissemination of positive messages to targeted groups. Turkey has many valuable assets with which to promote and build a strong image. 
What is needed is a strategic image management approach of integrated planning, implementation and promotion, one which will be effective in changing negative prejudices into positive images.

\section{REFERENCES}

Aaker, D. A. and Myers, J. G. (1987). Advertising Management. London, UK: Prentice Hall.

Altınbaşak, İ. (2004). "Modeling the Constituents of a Country for the Determination of Priorities Related to Strategic Image Management: The Case of Turkey," Ph.D. diss., Istanbul: Boğaziçi University Press.

----- (2008). "Developing and Managing Country Brands: An Initiative in Order to Investigate the Nation Brand Image of Turkey in Europe," 2008 Thought Leaders International Conference on Brand Management. University of Birmingham, UK.

Anholt, S. (2000). "The Nation as Brand," Across the Board, 12(1): 22-27.

Anholt S. (2005). "How the World Sees the World," Nation Brands Index. Available [online] at: htpp://www.gmi_mr.com/gmipoll/docs/NBI_Q1_2005.pdf (download 08/06/2007)

Bannister, J.P. and Saunders, J.A. (2001). “UK Consumers Attitudes towards Imports: The Measurement of National Stereotype Image,” European Journal of Marketing, 12: 562-570.

Dunn, S. W. and Barban, A. M. (1982). Advertising: Its Role in Modern Marketing. Winston: The Dryden Press.

Eurobarameter (2006). Available [online] at: http://ec.europa.eu/public_opinion/index_en.htm Accessed on 18/02/2008.

Erickson, G. M., Johansson, J., and Chao, P. (1984). "Image Variables in Multi-Attribute Product Evaluations: Country of Origin Effect," Journal of Consumer Research, 11: 649-699.

Ger,G. and Askegaard, S. (1996). Product-Country Images as Stereotypes: A Comparative Study. 1328. Paris: IAREP.

Han, C.M. (1989). "Country Image: Halo or Summary Construct," Journal of Marketing Research, 26(2),(May): 222-229.

Herzog, H. (1963). "Behavioral Science Concepts for Analyzing the Consumer," in P. Billis (ed.). Marketing and the Behavioral Sciences: 76-86. Boston: Allyn and Bacon, Inc.

Ingrid, M. and Eroğlu, S. ( 1993 ). "Measuring a Multidimensional Construct: Country Image,” Journal of Business Research, 28:191-120.

Johansson, J.K., Douglas, S.P., and Nonaka, I. (1985). "Assessing the Impact of Country of Origin on Product Evaluations: A New Methodological Perspective," Journal of Marketing Research, 19: 388-396. 
Kemming, J.D. and Sandıkçı, Ö. (2007). “Turkey's EU Accession as a Question of Nation Brand Image," Place Branding and Public Diplomacy, 3(1): 31-41.

Laroche, M., Papadopulos, N., and Heslop, A.L. (2005). "The Influence of Country and Image Structure on Consumer Evaluations Of Foreign Products," International Marketing Review, 22(1): 96-115.

Martin, I. and Eroğlu, S. (1993). “Measuring a Multi-Dimensional Construct: Country Image,” Journal of Business Research, 28: 191-210.

Martineau, P. (1987). Motivation in Advertising. (p. 146). New York: McGraw Hill, Inc.

Morello, G. (1984). "The 'Made In' Issue - A Comparative Research on the Image of Domestic and Foreign Products," European Research, 12(1): 5-21.

Niss, H. (1996). "Country of Origin Marketing over the Product Life Cycle: A Danish Case Study," European Journal of Marketing, 30(3): 6-22.

Scott, L. and Johnson, K. (2005). "The Automatic Country-of-Origin Effects on Brand Judgements," Journal of Advertising, 34 (1): 87-98.

Srikatanyoo, N. and Gnoth, J. "National Branding Country Image and International Tertialy Education," Journal of Brand Management, 10(2): 139-146.

Weber, R.P. (1990). Basic Content Analysis, $2^{\text {nd }}$ ed., Sage University Papers, no. 49, Sage Publications.

Zimmer, M.R. and Golden, L. (1988). "Impressions of Retail Stores: A Content Analysis of Consumer Images," Journal of Retailing, 64(3): 280-293. 


\section{APPENDIX 1}

\section{DISCUSSION GUIDE}

I would like to thank for your participation. Your opinion and ideas are very important for the research. The results will only be used for academic purposes and your names will not be mentioned. Therefore, please share your ideas freely.

Could you please tell me your name, age, profession, the duration and reason of your stay in Turkey?

According to you what is a prejudice? Are prejudices important in the creation of the image of a country?

What were the prejudices that you had/have about Turkey before your experience?

What were the sources of those prejudices?

After you have experienced it, what is the image of Turkey for you?

Which prejudices have been proven right or wrong? Why and how?

In order to overcome the prejudices and improve the current image of Turkey what would you suggest? What are the main issues to be concentrated on?

Thank you.

\section{APPENDIX 2}

\section{METHODOLOGY OF CONTENT AND RELIABILITY ANALYSIS}

Content analysis typically produces numerical descriptions of the data. A central idea is that many words of a text are classified into much fewer content categories. This technique requires the objective, systematic and quantitative description of the manifest content of communication (Zimmer and Golden, 1988).

Following the requirements, an analysis of the texts of the focus group interviews is carried out. The stages involved are:

1. The researcher codes the subjects' answers into a list of themes.

2. The researcher groups the themes into mutually exclusive and exhaustive categories.

3. Two independent sorters group the themes under certain categories.

4. The researcher and the sorters discuss the reasoning behind the classification and come up with an agreed categorization.

5. Two judges (different from the sorters) are asked to group the themes in the agreed categories. 
For the content analysis, Zimmer and Golden's method (1988) was applied. Two judges were given the themes (n) and instructed to assign each theme to one of the categories best describing its content.

32 (k) out of 40 items matched related to prejudices themes. As a next step, a z-score was calculated to find out the probability of obtaining 32 or more matches.

E: expected number of matches

p: probability that two judges assign a theme to the same category:1/11

$\mathrm{k}$ : items matched:32

$z=\frac{k-E}{\sqrt{n p(1-p)}}$

$\mathrm{z}=15.6$

Number of matches: 32 Percentage of Matches: $80 \%$. Z score: 15.6

Since the z-score calculated exceeds a z-score of 2.33 corresponding to an alpha of 0.01 , the result is significant. This shows significant agreement between the judges, far greater than what could be attributed to chance.

$38(\mathrm{k})$ out of 46 items matched related to image themes. As a next step, a z-score was calculated to find out the probability of obtaining 38 or more matches.

E: expected number of matches

p: probability that two judges assign a theme to the same category:1/12

k: items matched: 38

$z=\frac{k-E}{\sqrt{n p(1-p)}}$

$\mathrm{Z}=18.22$

Number of matches: 38 Percentage of Matches: $83 \% \quad \mathrm{Z}$ score: 18.22.

Since the z-score calculated exceeds a z-score of 2.33 corresponding to an alpha of 0.01 , the result is significant. This shows significant agreement between the judges, far greater than what could be attributed to chance.

The following formula is used to calculate the reliability figure, where,

$R=\frac{N^{*} \text { AverageAgreement }}{[1+(N-1) * \text { AverageAgreement }]}$

$\mathrm{N}$ : Number of Judges: 2

Average Agreement: $32 / 40$ for prejudice themes $\quad R=0.88$ for prejudice themes

Average Agreement: $38 / 46$ for image themes $\quad R=0.90$ for image themes 